\title{
The Distribution of Systemic Diseases According to Age and Gender in Patients Admitted to an Oral and Dental Health Care Hospital
}

\section{Ağız ve Diș Sağlığı Hastanesine Başvuran Hastalarda Sistemik Hastalıkların Yaș ve Cinsiyete Göre Dağılımı}

\author{
Elif Aybala Oktay', Serpil Karaoglanoglu', Numan Aydın' ${ }^{1}$ Zeynep Yeșil Duymuş², \\ Tuğgen Özcivelek Mersin ${ }^{3}$, Hüseyin Tort ${ }^{4}$ \\ 'Department of Restorative Dentistry, University of Health Sciences, Ankara, Turkey \\ ${ }^{2}$ Department of Prosthodontics, University of Recep Tayyip Erdoğan, Rize, Turkey \\ 3Department of Prosthodontics, University of Health Sciences, Ankara, Turkey \\ 4Balgat Oral and Dental Health Center, Ankara, Turkey
}

\begin{abstract}
Objectives: Investigation of systemic disorders of adult patients prior to dental interventions is of great importance in order to take relevant precautions and prevent possible complications. The aim of this study is to determine the frequency and distribution of various systemic diseases in adult patients who admitted to the outpatient clinic of an oral and dental health care hospital.

Materials and Methods: Study group included a total of 440 patients, 251 females and 189 males aged between 18 to 80 years who admitted to Oral and Dental Health Care Hospital for dental care. The distribution and frequency of various systemic diseases were determined by questioning the medical history of the patients with standard self-reported anamnestic questionnaires and verbal interviews. Data were analysed by Chi square test using SPSS Statistical Package Program ( $\mathrm{p}<0.05)$.

Results: In $24.31 \%(n=107)$ of the study group only one disease was detected and in $15.68 \%(n=69)$ more than one systemic disease were detected, whereas no disease was detected in $60.00 \%(n=264)$. The most prevalent disease encountered in the study group was cardio-vascular disorders $(13.40 \%, \mathrm{n}=59)$, and the second one was endocrine diseases $(12.27 \%, \mathrm{n}=54)$.

Conclusions: In conclusion, detailed medical histories of the patients may be helpful in prevention of complications related with systemic diseases and ensure optimal treatment performances.

Key words: Oral and dental health care hospital, dentistry, systemic diseases
\end{abstract}

$\ddot{O} \mathbf{z}$

Amaç: Diş hekimliği müdahalelerinden önce erişkin hastaların sistemik rahatsızlıklarının araștırılması, gerekli önlemlerin alınması ve olası komplikasyonların önlenmesi için büyük önem taşımaktadır. Bu çalıșmanın amacı bir ağız ve diş sağlığı hastanesi polikliniğine başvuran erişkin hastalarda çeșitli sistemik hastalıkların sıklığını ve dağılımını belirlemektir.

Materyal ve Metot: Çalışma grubuna, Diş Sağlığı Hastanesi'ne başvuran 18-8o yaşları arasında 251 kadın ve 189 erkek toplam 440 hasta dahil edildi. Hastalardan alınan anamnezde tıbbi öykü sorgulanarak çeşitli sistemik hastalıkların dağılımı ve sıklı̆̆ı belirlendi. Veriler SPSS İstatistiksel Paket Programı kullanılarak Ki-kare testi ile analiz edildi $(\mathrm{p}<0,05)$.

Bulgular: Çalıșma grubunun \%24,31'inde sadece bir, \%15,68'inde birden fazla sistemik hastalık saptanırken \%6o,oo'ında hastalık saptanmadı. Çalışma grubunda en sık rastlanan hastalığın kardiyovasküler bozukluklar $(\% 13,40)$, ikincisinin ise endokrin hastalıklar $(\% 12,27)$ olduğu tespit edildi.

Sonuç: Sonuç olarak, hastaların ayrıntılı tıbbi öykülerinin alınması, sistemik hastalıklarla ilişkili komplikasyonların önlenmesinde yardımcı olabilir ve optimal tedavi performansını sağlayabilir.

Anahtar Kelimeler: Ağız ve diş sağlığı hastanesi, diş hekimliği, sistemik hastalıklar

\section{Yazıșma Adresi / Correspondence:}

Dr. Elif Aybala Oktay

e-mail: elifaybala.oktay@sbu.edu.tr

Date of submission: 08.11.2018

Date of admission: 27.05.2019 
The Distribution of Systemic Diseases According to Age and Gender in Patients Admitted to an Oral and Dental Health Care Hospital

\section{Introduction}

Currently cardiovascular diseases, diabetes, chronic respiratory diseases and cancers are some of the important systemic diseases that influence all societies and constitute $60 \%$ of deaths. Most frequently detected systemic disorders in Turkey influence as much people as 15 million people with hypertension, 4 million with diabetes, 3 million with chronic obstructive pulmonary disease and 2 million with coronary heart disease. ${ }^{1}$ More than 200 oral signs of systemic diseases have been reported by the American Dental Association (ADA) due to heredity, age, gender, lifestyle, smoking, diet and obesity as a result of industrial and economic developments. ${ }^{2}$ Additionally the world oral health report by WHO at year 2003 emphasized the importance of dental and oral health and suggested to consider it together with general health as a whole complex structure. $^{3}$

Detailed anamnesis of the patients referring to the dental clinics maintains valuable data to clarify the medical history, current general health status, the medications used for their systemic diseases and to plan the treatment appropriately in accordance with these data. The accurate diagnosis of intraoral signs of systemic diseases guides the dental treatment planning. ${ }^{4}$ Moreover prior awareness of systemic diseases allows for wise approaches by consultation, taking relevant precautions such as modified local anesthesia applications when necessary and reduce the incidence of complications in dental treatments. ${ }^{5}$

Statistical information on the distribution and frequency of systemic diseases in the community needs to be updated. The aim of this study is to examine the incidence of systemic disorders and their relationship with gender, age of patients from 18 to 80 years of ages, who admitted to our hospital.

\section{Materials and Methods}

This study was conducted at an Oral and Dental Health Care Hospital with approval of Ethics Committee for Clinical Researches. Within the scope of the study, 500 patients between 18 to 80 years of age that admitted to the hospital between SeptemberNovember 2017 were randomly referred to the five dentists according to the order of submission from the patient admission unit. Dentists who were responsible from data collection had at least ten years of occupational experience. The purpose of the study was explained to the patients, 6o of them did not want to participate to the study with different reasons and were excluded from the study group. Informed consent form was signed by 440 volunteers before filling in the face to face questionnaire forms.

Sociodemographic data such as gender, age and systemic disorders of the patients were recorded. Patients were grouped in five groups as 18-30, 31-40, 41-50, 51-6o and 61-80 years with respect to their age.

Statistical data analysis was performed using the SPSS 22.0 Statistics program (SPSS Inc., Chicago, IL, USA). The Pearson Chi-square test used for the analysis of the data ( $<<0.05)$.

\section{Results}

According to the general health status, $60.00 \%(n=264)$ of the study group were discriminated as healthy while $24.31 \%(n=107)$ of them had only one systemic disease and $15.68 \%(n=69)$ had more than one systemic disease (Figure 1$)$. 
The Distribution of Systemic Diseases According to Age and Gender in Patients Admitted to an Oral and Dental Health Care Hospital

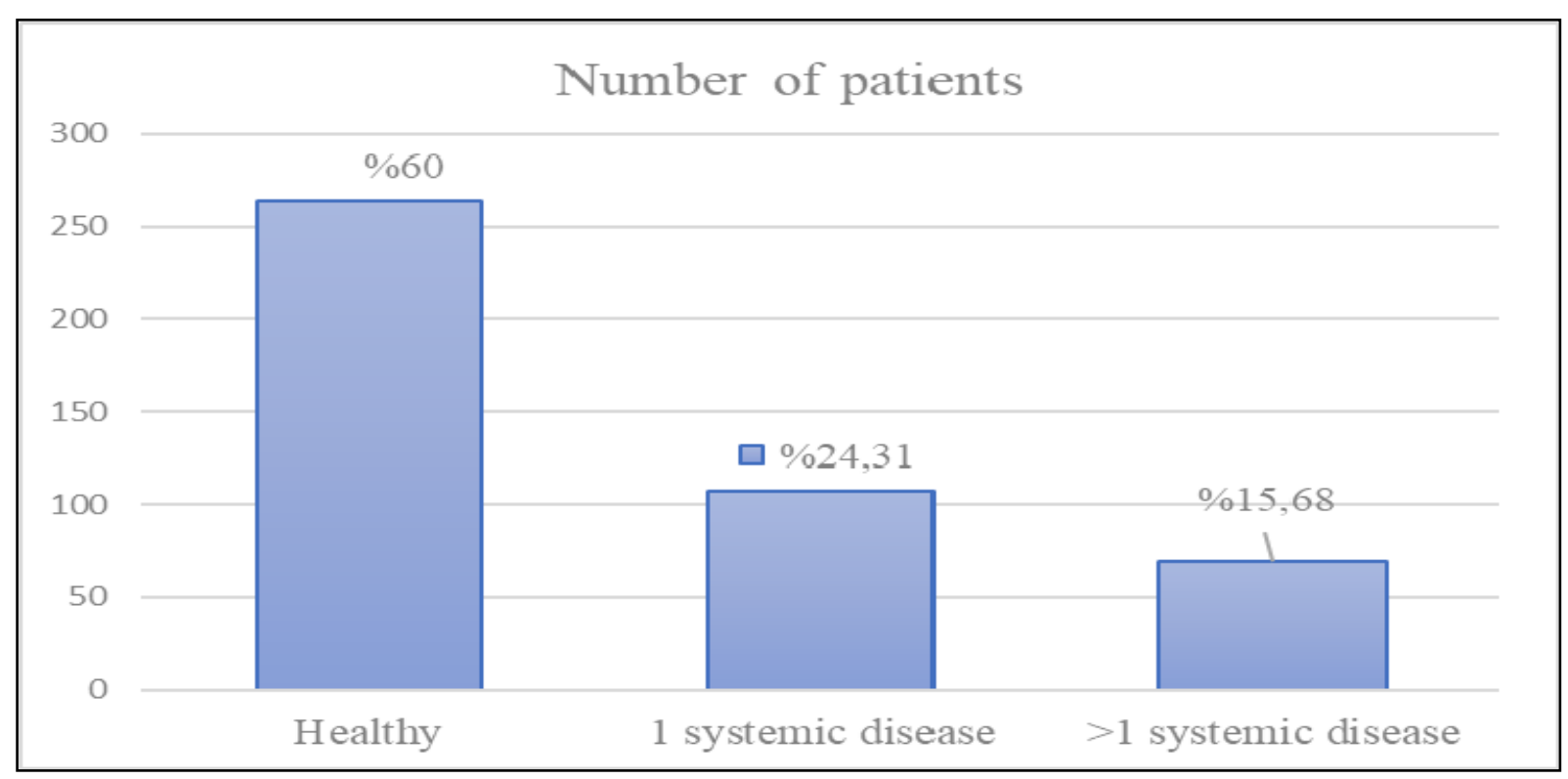

Figure 1. Health status of study group in \%

The distribution of systemic diseases observed according to the data obtained from our study was shown in the Table 1 . Systemic diseases detected were cardiovascular $(13.40 \%)$, endocrine $(12.27 \%)$, gastrointestinal (10.90\%), respiratory system $(8.63 \%)$, hematologic $(6.81 \%)$, autoimmune $(5.00 \%)$, skeletal and joint $(2.72 \%)$, cancer $(2.50 \%)$, psychological (2.50\%), hepatobiliary (2.27\%) and neurological disorders $(2.04 \%)$. Cardiovascular, endocrine, autoimmune, gastrointestinal and hematologic diseases were more frequent in women compared to men.

Table 1. Distribution of systemic diseases in the study group (n and \%)

\begin{tabular}{|l|c|c|}
\hline Diseases & $\mathbf{n}$ & $\%$ \\
\hline Cardiovascular & 59 & 13.40 \\
\hline Endocrine & 54 & 12.27 \\
\hline Gastrointestinal & 48 & 10.90 \\
\hline Respiratory & 38 & 8.63 \\
\hline Hematologic & 30 & 6.81 \\
\hline Autoimmune & 22 & 5.00 \\
\hline Skeletal and joint & 12 & 2.72 \\
\hline Cancer & 11 & 2.50 \\
\hline Psychologic & 11 & 2.50 \\
\hline Hepatobiliary & 10 & 2.27 \\
\hline Neurological & 9 & 2.04 \\
\hline
\end{tabular}


The Distribution of Systemic Diseases According to Age and Gender in Patients Admitted to an Oral and Dental Health Care Hospital

Distribution of cardiovascular and endocrine diseases according to age groups was statistically significant $(\mathrm{p}<0.001)$, (Table 2 ). This significant difference was found to be due to the greater number of patients in 51-6o and 61-80 years of age groups. There was no statistically significant difference between cardiovascular and endocrine diseases in other age groups.

Table 2. Distribution of systemic diseases with respect to age groups.

\begin{tabular}{|c|c|c|c|c|c|c|c|c|c|c|c|c|c|c|c|c|c|c|c|c|c|c|}
\hline \multirow{3}{*}{ 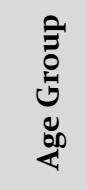 } & \multicolumn{22}{|c|}{ Systemic Disorders (n) } \\
\hline & \multicolumn{2}{|c|}{ CV } & \multicolumn{2}{|c|}{ Auto } & \multicolumn{2}{|c|}{ GIS } & \multicolumn{2}{|c|}{ Hem } & \multicolumn{2}{|c|}{ HB } & \multicolumn{2}{|c|}{ Res } & \multicolumn{2}{|c|}{ Neur } & \multicolumn{2}{|c|}{ Psy } & \multicolumn{2}{|c|}{ Endo } & \multicolumn{2}{|c|}{ Cancer } & \multicolumn{2}{|c|}{ SJ } \\
\hline & + & - & + & - & + & - & + & - & + & - & + & - & + & - & + & - & + & - & + & - & + & - \\
\hline $18-30$ & 2 & 119 & 2 & 119 & 5 & 116 & 8 & 113 & 1 & 120 & 9 & 112 & 1 & 120 & o & 121 & 8 & 113 & 1 & 120 & $\mathrm{o}$ & 121 \\
\hline $31-40$ & 6 & 106 & 1 & 111 & 11 & 101 & 5 & 107 & 1 & 111 & 6 & 106 & 1 & 111 & 1 & 111 & 6 & 106 & 1 & 111 & 2 & 110 \\
\hline $41-50$ & 14 & 68 & 11 & 71 & 12 & 70 & 11 & 71 & 2 & 80 & 11 & 71 & 3 & 79 & 5 & 77 & 11 & 71 & 2 & 80 & 3 & 79 \\
\hline $51-60$ & 20 & 57 & 4 & 73 & 15 & 62 & 4 & 73 & 4 & 73 & 6 & 71 & 2 & 75 & 4 & 73 & 19 & 58 & 2 & 75 & 2 & 75 \\
\hline $61-80$ & 17 & 31 & 4 & 44 & 5 & 43 & 2 & 46 & 2 & 46 & 6 & 42 & 2 & 46 & 1 & 47 & 10 & 38 & 5 & 43 & 5 & 43 \\
\hline Total & 59 & 381 & 418 & 22 & 48 & 392 & 30 & 410 & 10 & 430 & 38 & 402 & 9 & 431 & 11 & 429 & 54 & 386 & 11 & 429 & 12 & 428 \\
\hline $\mathbf{p}$ & $<0$ & $01^{*}$ & o.o & ** & 0.0 & & & & & ${ }^{* *}$ & & 223 & & $93^{* *}$ & & $\mathbf{0}^{* *}$ & & $\mathrm{Do1}^{*}$ & & $02^{* *}$ & & $01^{* *}$ \\
\hline
\end{tabular}

+: Yes, -: No , CV: Cardiovascular, Auto: Autoimmune Disease, GIS: Gastrointestinal System Disease, Hem: Hematologic Disease, HB: Hepatobiliary Disease, Res: Respiratory System Disease, Neur: Neurologic Disease, Psy: Psychologic Disease, SJ: Skeletal and Joint Disease. ${ }^{*} \mathrm{p}<0.05,{ }^{* *}$ More than $20 \%$ of the cells have missing frequencies.

While neurological $(\mathrm{p}=0.409)$, hepatobiliary $(\mathrm{p}=0.309)$, psychological $(\mathrm{p}=0.228)$, skeletal and joint $(\mathrm{p}=0.355)$, malign diseases $(\mathrm{p}=0.228)$ did not show significant difference with male and female patients; cardiovascular $(\mathrm{p}=0.025)$, respiratory $(\mathrm{p}=0.047)$, autoimmune $(\mathrm{p}<0.001)$, gastrointestinal $(\mathrm{p}=\mathrm{o.013})$, hematologic $(\mathrm{p}=\mathrm{0.002})$ and endocrine diseases $(\mathrm{p}=0.005)$ were significantly higher in female patients than in male patients (Table 3 ).

\section{Discussion}

In order to take necessary precautions and prevent the possible stringent effects on the treatment process, it is crucial to know the systemic health issues and drugs used by the patient for the dentist. ${ }^{6}$

In the literature the incidence of systemic diseases in adult patients was reported between $27.00 \%$ and $52.50 \%$ by other dental practitioners..$^{7-9}$ In our study, the current systemic diseases were investigated considering the age and gender of adult patients who admitted to our hospital in three months' time. According to the data of 251 women and 189 men, totally 440 participants, 107 patients who constitute $24.31 \%$ of the cohort, had at least one systemic disease. In accordance with our study, the incidence of systemic disease at a dental surgery clinic was reported as $36.50 \%$ in another study. ${ }^{5}$ It was reported that consultation request rates were as $29.60 \%$ and $28.90 \%$ for cardiology and internal medicine, respectively. ${ }^{10}$ In the light of these findings high 
The Distribution of Systemic Diseases According to Age and Gender in Patients Admitted to an Oral and Dental Health Care Hospital

incidence of systemic disorders points out to the importance of patients' history and taking relevant precautions.

Table 3. Distribution of systemic diseases with respect to gender.

\begin{tabular}{|c|c|c|c|c|c|c|c|c|c|c|c|c|c|c|c|c|c|c|c|c|c|c|}
\hline \multirow{3}{*}{ Gender } & \multicolumn{22}{|c|}{ Systemic Disorders (n) } \\
\hline & \multicolumn{2}{|c|}{$\mathrm{CV}$} & \multicolumn{2}{|c|}{ Auto } & \multicolumn{2}{|c|}{ GIS } & \multicolumn{2}{|c|}{ Hem } & \multicolumn{2}{|c|}{ HB } & \multicolumn{2}{|c|}{ Res } & \multicolumn{2}{|c|}{ Neur } & \multicolumn{2}{|c|}{ Psy } & \multicolumn{2}{|c|}{ Endo } & \multicolumn{2}{|c|}{ Cancer } & \multicolumn{2}{|c|}{ SJ } \\
\hline & + & - & + & - & + & - & + & - & + & - & + & - & + & - & + & - & + & - & + & - & + & - \\
\hline Female & 41 & 210 & 20 & 231 & 35 & 216 & 25 & 226 & 7 & 244 & 27 & 224 & 6 & 245 & 8 & 243 & 40 & 211 & 8 & 243 & 8 & 243 \\
\hline Male & 18 & 171 & 2 & 187 & 13 & 176 & 5 & 184 & 3 & 186 & 11 & 178 & 3 & 186 & 3 & 186 & 14 & 175 & 3 & 186 & 4 & 185 \\
\hline Total & 59 & 381 & 22 & 418 & 48 & 392 & 30 & 410 & 10 & 430 & 38 & 402 & 9 & 431 & 11 & 429 & 54 & 386 & 11 & 429 & 12 & 428 \\
\hline $\mathbf{p}$ & \multicolumn{2}{|c|}{$0.025^{*}$} & \multicolumn{2}{|c|}{$<0.001^{*}$} & \multicolumn{2}{|c|}{$0.013^{*}$} & \multicolumn{2}{|c|}{$0.002^{*}$} & \multicolumn{2}{|c|}{0.309} & \multicolumn{2}{|c|}{$0.047^{*}$} & \multicolumn{2}{|c|}{0.409} & \multicolumn{2}{|c|}{0.228} & \multicolumn{2}{|c|}{$0.005^{*}$} & \multicolumn{2}{|c|}{0.228} & \multicolumn{2}{|c|}{0.355} \\
\hline
\end{tabular}

+: Yes, -: No, CV: Cardiovascular, Auto: Autoimmune Disease, GIS: Gastrointestinal System Disease, Hem: Hematologic Disease, HB: Hepatobiliary Disease, Res: Respiratory System Disease, Neur:

Neurologic Disease, Psy: Psychologic Disease, SJ: Skeletal and Joint Disease. ${ }^{*} \mathrm{p}<0.05$

In Turkey heart diseases were reported in the first rank among all causes of death, with rates ranging from $40 \%$ to $45 \% .{ }^{1}$ Aydıntuğ et al. reported the most common systemic disease as cardio vascular diseases with $18.56 \%$ of their study. ${ }^{4}$ In our study cardio vascular diseases were also the most common disease with $13.40 \%(n=59)$.

Cardiovascular diseases were detected in $16.33 \%(n=41)$ of women and $9.52 \%(n=18)$ of men in our study group and the difference between gender groups were statistically significant $(\mathrm{p}=0.025)$. Additionally, similar to Aydıntuğ et al.'s results ${ }^{4}$, hypertension was the most common disease among the cardiovascular diseases in our study with 9.09\% $(\mathrm{n}=40)$. Environmental and genetic factors have been defined to have an influence in the emergence of cardio vascular diseases. ${ }^{11}$ In recent years, obesity displays an inclining trend in the society. ${ }^{12}$ Presumptively due to hyperinsulinemia triggered by obesity, triglyceride levels increase, and this affects the HDL cholesterol levels negatively.13 Another environmental factor smoking is also a risk for cardiovascular diseases. ${ }^{14}$ Despite the decrease in men, smoking tends to increase in women which might explain the higher prevalence of cardiovascular diseases in women.

Ischemic heart disease, which is common in people over 65 years of age in America, is the most important cause of elderly deaths. ${ }^{15}$ For this reason, dentists should be ready and well-equipped to provide emergency care and basic cardiopulmonary resuscitation (CPR). Patients with heart failures should take their regular medications on the day of the dental intervention and inform the dentist about the medication they take. ${ }^{16,17}$ Elderly people are increasing in number in the population and as a preventive measure for the elderly patients' oral health issues, frequent control appointments are recommended. One to three-month controls are also suitable for patients with systemic problems which are known to affect oral tissues. ${ }^{18}$

In a study on asthma patients gender differences were related to age groups and the disease was more severe and disabling in the female population. ${ }^{19}$ In our study, respiratory system diseases were related with gender $(\mathrm{p}=0.047)$ whereas no significant difference was found with respect to age groups $(\mathrm{p}=0.223)$. The incidence of respiratory diseases was $10.75 \%(n=27)$ in females and $5.82 \%(n=11)$ in males. Studies that 
The Distribution of Systemic Diseases According to Age and Gender in Patients Admitted to an Oral and Dental Health Care Hospital

investigate the relationship between poor oral hygiene and systemic diseases revealed that chronic diseases of respiratory system are also related with poor oral hygiene. ${ }^{20-21}$

In patients with chronic obstructive pulmonary disease (COPD) dentists should be cautious to keep the patient in an upright position during the dental procedure, refrain to use hypnotic, antihistaminic, anticholinergic, narcotic analgesics as much as possible, avoid the use of macrolide group antibiotics in the patients taking theophylline and consult the patients who are on corticosteroids with the medical practitioner. $^{22}$ In cases of active tuberculosis no dental procedure should be performed except from emergencies. When compulsory, the dentist must work with double pair of gloves and protective mask. Antiseptic mouthwashes should be used to rinse the mouth at the beginning of the procedure to prevent tuberculous bacilli spread. It has been reported that routine dental treatment can be performed in patients who have had previous tuberculosis or positive tuberculin test results and have no history of tuberculosis. ${ }^{22}$

Diabetes is the most common endocrine disease. The incidence of diabetes is reported as $13.70 \%$ in Turkey's Diabetes Epidemiology Study-II ${ }^{23}$ Aydıntug et al. reported endocrinological diseases rate as $8.28 \%$ and diabetes rate was $57.83 \%$ among all endocrinological diseases. ${ }^{4}$ In our study, endocrine diseases were detected in $12.27 \%$ $(n=54)$ of the study group and $4.77 \%(n=21)$ of these patients had diabetes. Statistically significant relationship between endocrine diseases with respect to age groups and gender was found. Emergency protocols for these patients should be determined by taking the status of consciousness of the patient during dental interventions into account. At the beginning of the procedure oral glucose jellies and tablets should be ready for use in the risk of hypoglycemia and insulin users should measure blood glucose levels by bringing in their measurement devices with them. ${ }^{24}$

Infectious diseases caused by hepatitis viruses has a remarkable part among the infectious diseases that should be noticed by dental practitioner. Being one of the hepatobiliary system diseases, hepatitis is a major thread for the public health. ${ }^{25}$ Recent studies reveal that Hepatitis B Virus (HBV) carrier ratios differ between countries from $0.15 \%$ to $15.00 \% .{ }^{26,27}$ In our study $1.59 \%(n=7)$ of the patients have had hepatitis. Implementation of strict preventive measures for disinfection and sterilization before and after dental treatment of all patients is critical for the prevention of transmission of the disease to medical staff and other patients.

Dental treatment planning of patients with cancers are essential for dentists since patients receive additional treatments such as radiation therapy and chemotherapy which have side effects on oral tissues. Treatment planning considerations may be altered due to the medical history of the patient. ${ }^{28}$ Mucous inflammation of the oral cavity, tongue, and throat (mucositis), bleeding, pain, or changes of taste occur as side effects of radiotherapy. Since oral mucosa has high turnover rate, it is more susceptible to trauma. Important issues encountered in these patients is xerostomia and rapid tooth decay. the loss of salivary buffering capacity, and low level of immunoglobulins contribute to the development of prosthetic stomatitis. ${ }^{29}$ So, during radiotherapy and chemotherapy discontinuation of prosthesis use is recommended. ${ }^{1}$ In our study no statistically significant difference was observed for cancer between age groups and gender. 
The Distribution of Systemic Diseases According to Age and Gender in Patients Admitted to an Oral and Dental Health Care Hospital

Anemia, one of the hematologic disorders, should be taken into account by the dentist prior to treatment planning. While anemia was significantly higher in women, there was no statistically significant relation with age parameters in our study group.

Studies on health sciences and demographic variables indicate that the risk of having at least one chronic illness increases with age. Increased life span has led to notion on quality of life in old ages and increase in health expenditures especially in developing countries. ${ }^{30}$

Within the limitations of our study although our study group might be inadequate to reflect the whole population, we hope it might draw attention to many possible issues that may be encountered in dental clinics.

\section{Conclusion}

According to the results of our study, the presence of at least one or more systemic diseases in $40 \%$ of the study group points out the importance of taking detailed anamnesis from patients before dental procedures. It is important for the dentist to enlighten the general health status and medical history, to anticipate the complications that may occur during and after the treatment, and to take necessary precautions for the patients. Studies on the frequency and distribution of systemic diseases in the society may contribute to dentist's approach to patients.

\section{Acknowledgments}

Author contributions: Concept; S.K. and Z.Y.D., design; S.K. and Z.Y.D., supervision; S.K., Z.Y.D., E.A.O. and T.Ö.M., data collection E/or processing; T.Ö.M, H.T. and S.K. and N.A., analysis E/or interpretation; S.K., T.Ö.M., N.A. and E.A.O., literature search; N.A and E.A.O., writing; E.A.O., N.A., H.T. and T.Ö.M., critical review; S.K. and Z.Y.D. No financial support was received from any source for this work.

This study was presented in TDB 24 th International Dental Congress as oral presentation.

\section{Conflict of Interest}

The authors declared they do not have anything to disclose regarding conflict of interest with respect to this manuscript.

\section{References}

1. Vural Koç U, Vural CA, Gokalp S. Non-communicable diseases and dental caries. J Dent Fac Ataturk Uni. 2016; (suppl. 15):80-86.

2. Bokhari SA, Khan AA. Growing burden of noncommunicable diseases: the contributory role of oral diseases, Eastern Mediterranean Region perspective. East Mediterr Health Journal. 2009;15(4): 1011-1020.

3. Petersen PE. The World Oral health report 2003: continuous improvement of oral health in the 21st century - the approach of the WHO global oral health programme. Community Dent Oral Epidemiol. 2003; 31(suppl. 1):3-24. 
The Distribution of Systemic Diseases According to Age and Gender in Patients Admitted to an Oral and Dental Health Care Hospital

4. Aydıntug YS, Sencimen M, Bayar GR, Mutlu I, Bayar A. The frequency of various systemic diseases in adult patients admitting to the department of oral and maxillofacial surgery outpatient clinic. Gulhane Medical Journal. 2010; 52:7-10.

5. Bodrumlu E, Aydın U, Özsevik AS. Systemic Health Status of the Cases Applying to the Endodontic Clinic. Turkiye Klinikleri J Dental Sci. 2008;14(1):1-5.

6. Radfar L, Suresh L. Medical profile of a dental school patient population. Journal of Dental Education. 2007; 71(5):682-686.

7. Fenlon MR, McCartan BE. Medical status of patients attending a primary care dental practice in Ireland. J Ir Dent Assoc. 1991;37(3-4):75-77.

8. De Jong KJ, Oosting J, Peters GJ, Abraham-Inpijn L. Detecting medical problems in dentistry: a survey of 4,087 patients in the Netherlands. Eur J Med. 1992;1(1):23-29.

9. Peacock ME, Carson RE. Frequency of self-reported medical conditions in periodontal patients. J Periodontol. 1995; 66(11):1004-1007.

10. Hatipoglu MG, Hatipoglu H. Evaluation of medical consultations forms of a patient group admitted to the dental clinic of a university hospital. Ankara Med J. 2015; 15(1):10-15.

11. Van Laer SD, Snijder MB, Agyemang C, Peters RJ, Van den Born B-JH. Ethnic differences in hypertension prevalence and contributing determinants - the HELIUS study. European Journal of Preventive Cardiology. 2018;0(oo):1-9.

12. Onat A, Keleș İ, Sansoy V, Ceyhan K, Uysal Ö, Çetinkaya A. at el. Rising Obesity Indices in 10year Follow-up of Turkish Men and Women: Body Mass Index Independent Predictor of Coronary Events Among Men. Turk Kardiyol Dern Ars. 20o1; 29(7): 430-436

13. Onat A, Yıldırım B, Erer B, Başar Ö, Çetinkaya A, Ceyhan K. at el Total Cholesterol/HDLcholesterol Ratio Best Lipid Predictor of Coronary Disease in Turkish Adults: Mean Triglyceride Levels Rise by 1 mg/dl Per Year. Turk Kardiyol Dern Ars. 2001; 29(6):334-343

14. Onat A, Başar Ö, Erer B, Ceyhan K, Yıldırım B, Keleș İ. at el. Prevalence, Relationship to HDL and Impact on Coronary Events of Smoking in Turkish Adults. Turk Kardiyol Dern Ars. 20o1; 29(8): 493-498

15. Hupp JR. Ischemic heart disease: dental management considerations. Dent Clin North Am. 2006;50(4):483-491.

16. Andreotti F, Davies GJ, Hackett DR, et al. Major Circadian Fluctuations in Fibrinolytic Factors and Possible Relevance to Time of Onset of Myocardial Infarction, Sudden Cardiac Death and Stroke. The American Journal of Cardiology. 1988;62(9):635-637.

17. Panza JA, Epstein SE, Quyyumi AA. Circadian variation in vascular tone and its relation to alpha-sympathetic vasoconstrictor activity. New England Journal of Medicine. 1991;325(14): 986990.

18. Uzun H, Nazlıel H. Medıcal, Dental History And Extraoral, İntraoral And Dental Findıngs In The Elderly. Turkish Journal of Geriatrics. 2000;3(1):15-21.

19. Cadeddu C, Capizzi S, Colombo D, Nica M, De AB. Literature review of gender differences in respiratory conditions: a focus on asthma and chronic obstructive pulmonary disease (COPD). Igiene e Sanita Pubblica. 2016; 72(5): 481-504.

20. Chung JH, Hwang HJ, Kim SH, Kim TH. Associations between periodontitis and chronic obstructive pulmonary disease; the 2010 to 2012 Korean National Health and Nutrition Examination Survey. Journal of Periodontology. 2016; 87(8): 864-871.

21. Gomes-Filho IS, Passos JS, Seixas da Cruz S. Respiratory disease and the role of oral bacteria. Journal of Oral Microbiology. 2010; 2(1): 5811.

22. Karaoglanoglu S. Dental Approach for Respiratory System Diseases. Turkiye Klinikleri Journal of Oral and Maxillofacial Surgery-Special Topics. 2017;3(2):72-76.

23. Muslu L, Ardahan M. Motivational interview technique for life style change in diabetes mellitus. Current Approaches in Psychiatry. 2018;10(3):336-347.

24. Elrick H, Stimmler L, Hlad CJ Jr, Arai Y. Plasma insülin response to oral and intravenous glucose administration. The Journal of Clinical Endocrinology \& Metabolism. 1964; 24(10): 1076-1082.

25. Tekin-Koruk S, Koruk İ, Şahin M, Duygu F. Evaluation of HBsAg, Anti-HBs and Anti-HCV Positivity and Risk Factors Among Oral and Dental Health Workers in Şanlıurfa. Klinik Journal. 2009; 22(2): 55-61.

26. Chen CJ, Wang LY, Yu MW. Epidemiology of hepatitis B viruse infection in the Asiapasific region. J Gastroenterol Hepatol. 2000; 15(2):3-6. 
The Distribution of Systemic Diseases According to Age and Gender in Patients Admitted to an Oral and Dental Health Care Hospital

27. Tandon BN, Acharya SK, Tandon A. Epidemiology of hepatitis B virus infection in India. Gut. 1996; 38(2):56-59.

28. Levi LE, Lalla RV. Dental Treatment Planning for the Patient with Oral Cancer. Dental Clinics of North America, 2018;62(1);121-130.

29. Rolski D, Kostrzewa-Janicka J, Zawadzki P, Życińska K, Mierzwińska-Nastalska E. The Management of Patients after Surgical Treatment of Maxillofacial Tumors. BioMed Research International. 2016; $1-7$.

30. Heyden G. Health profile of the ageing population: the Swedish experience. International Dental Journal. 1998; 48(3):167-172. 